\title{
In vitro anticandidal potency of Syzygium aromaticum (clove) extracts against vaginal candidiasis
}

\author{
Mohamed Taha Yassin *iD, Ashraf Abdel-Fattah Mostafa and Abdulaziz Abdulrahman Al-Askar
}

\begin{abstract}
Background: Candida vaginitis is a global health hazard that increases morbidity among women of childbearing age. Recent studies have revealed a high incidence of drug-resistant Candida strains. Additionally, treating Candida vulvovaginitis during pregnancy is challenging as antifungal therapy is associated with fetal abnormalities. Hence, it is important to develop novel therapeutic strategies to treat vulvovaginal candidiasis.
\end{abstract}

Methods: In this study, we used the disc diffusion method to evaluate the anticandidal activity of different Syzygium aromaticum extracts (methanol, ethyl acetate, n-hexane, and diethyl ether) against C. albicans, C. glabrata, and C. tropicalis. Furthermore, gas chromatography-mass spectrometry (GC-MS) analysis of different S. aromaticum extracts was performed to determine active components exhibiting anticandidal activity. Cytotoxicity of different clove extracts against the HUH7 cell line was evaluated.

Results: The ethyl acetate extract exhibited the highest antifungal activity against C. albicans, C. glabrata, and C. tropicalis with inhibition zone diameters of $20.9,14.9$, and $30.7 \mathrm{~mm}$, respectively. The minimum inhibitory concentration of the S. aromaticum ethyl acetate extract was $250 \mu \mathrm{g} / \mathrm{disc}$ against C. tropicalis, and $500 \mu \mathrm{g} / \mathrm{disc}$ against C. albicans and C. glabrata, while the minimum fungicidal concentration was $0.5 \mathrm{mg} /$ disc against $C$. tropicalis and $1 \mathrm{mg} /$ disc against the C. albicans and C. glabrata. GC-MS analysis of the ethyl acetate extract revealed the main bioactive compound as eugenol (58.88\%), followed by eugenyl acetate (23.86\%), transcaryophyllene (14.44\%), and a-humulene (1.88\%). The cytotoxicity assay indicated that the diethyl ether extract demonstrated the lowest toxicological effect against the $\mathrm{HUH7}$ cell line, with a relative $\mathrm{IC}_{50}$ of $62.43 \mathrm{\mu g} / \mathrm{ml}$; the methanolic extract demonstrated a higher toxicity $\left(I_{50}, 24.17 \mu \mathrm{g} / \mathrm{ml}\right)$.

Conclusion: As the S. aromaticum extract exhibited high antifungal activity at low concentrations, it can be a potential source of natural antifungal drugs.

Keywords: Candida vaginitis, Anticandidal bioassay, Syzygium aromaticum, GC-MS, Cytotoxicity

\section{Background}

Candidal vulvovaginitis is a common inflammatory disease among women, caused by an infection of the Candida species, especially C. albicans [1]. Candida vaginitis is characterized by vaginal discharge, pruritus, itching, dyspareunia, and erythematous vulva [2]. Epidemiological studies have indicated that C. albicans $(70.0-89.0 \%)$ is the main causative agent of Candida vaginitis, followed by C. glabrata (3.4-20.0\%)

\footnotetext{
* Correspondence: mohamed.yassin.ah2016@gmail.com Botany and Microbiology Department, College of Science, King Saud University, P.O. 2455, Riyadh 11451, Saudi Arabia
}

[3-6]. The high incidence of infection rates among pregnant women may be attributed to the high secretion of sex hormones during pregnancy $[7,8]$. A prescription of antifungal drugs during pregnancy is a challenging task as antifungals are accompanied by possible fetal toxicity and teratogenicity [9]. The virulence factors of the Candida species including hyphae formation, production of extracellular enzymes, adhesion, and biofilm formation, help in fungal colonization in the host and the establishment of fungal infection in the vagina [10-13]. Candida pathogens adhere to the epithelial cells of the vagina to

(c) The Author(s). 2020 Open Access This article is distributed under the terms of the Creative Commons Attribution 4.0 International License (http://creativecommons.org/licenses/by/4.0/), which permits unrestricted use, distribution, and 
initiate fungal infection through the production of proteins called adhesins [14]. Moreover, the formation of $C$. albicans pseudomycelium enhances the ability of the fungus to invade the host vaginal tissues [15]. Additionally, Candida species secrete several extracellular enzymes such as lipases, phospholipases, and hemolysins that aid in the adhesion and host tissue invasion [10]. In the USA, C. glabrata is the second most common causative agent of invasive candidiasis (12-18\%), reportedly exhibiting resistance against fluconazole [16]. An earlier study reported that approximately $94 \%$ of all C. albicans isolates from vaginitis patients exhibit resistance to fluconazole [17]. Furthermore, another study has reported that certain Candida isolates exhibit resistance to fluconazole and econazole [18]. Syzygium aromaticum (clove) is an aromatic medicinal plant that belongs to the Myrtaceae family [19]. Reportedly, clove oil possesses antifungal, antibacterial, antiviral, and insecticidal properties due to the presence of phytoactive compounds such as eugenol, eugenyl acetate, and $\beta$-caryophyllene [19-21]. The antifungal activity of $S$. aromaticum has been demonstrated by Khan et al. (2009), who reported that the ethanolic extract of clove was highly effective against C. albicans with a Minimum inhibitory concentration (MIC) value at $156 \mu \mathrm{g} / \mathrm{mL}$ [22]. The same result has been confirmed by Gonelimali et al. (2018) and Sahal et al. (2019), who detected the potency of clove extracts against $C$. albicans and C. tropicalis strains at concentrations of $20 \% \mathrm{w} / \mathrm{v}$ and $500 \mu \mathrm{l} / \mathrm{mL}$, with inhibition zones diameter of 25.2 and $28 \mathrm{~mm}$, respectively [23, 24]. The high incidence of vaginal candidiasis among pregnant women, in addition to the emergence of resistant Candida strains to different antifungal agents, enhances the necessity to formulate novel and safe natural therapeutic agents. Hence, this study aimed to investigate the anticandidal activity of different $S$. aromaticum extracts against three Candida species.

\section{Methods}

\section{Preparation of plant extracts}

The extraction procedure was performed using different organic solvents (methanol, ethyl acetate, diethyl ether, and n-hexane), demonstrating different polarities to allow the extraction of all hydrophilic and lipophilic bioactive compounds. The flower buds of $S$. aromaticum were obtained from a local market in Riyadh, Saudi Arabia. We identified the plant material and the identification was confirmed by the Saudi herbarium, Botany Department, College of Science, King Saud University. The plant material was deposited at the herbarium with a voucher number (KSU-14682). Clove buds were disinfected using 0.5\% sodium hypochlorite solution $(\mathrm{NaOCl})$, washed three successive times using sterile distilled water, and allowed to dry. The dried plant material was homogeneously powdered using a mechanical mortar. The powdered sample $(15 \mathrm{~g}$ ) was added to $200 \mathrm{~mL}$ of the different organic solvents and incubated on a magnetic stirrer for $48 \mathrm{~h}$. Next, the mixture was centrifuged at $9000 \mathrm{rpm}$ for $10 \mathrm{~min}$ to remove residues. The supernatant was filtered using a Whatman filter paper to obtain a clear filtrate. The filtrate was concentrated using a rotatory evaporator and stored at $4{ }^{\circ} \mathrm{C}$ until use. The yield of the extract was calculated using the following formula:

$$
\text { Percentage extract yield }=(\mathrm{R} / \mathrm{S}) \times 100
$$

where $\mathrm{R}$ is the weight of the residue of the plant extract; $\mathrm{S}$ is the raw plant sample weight.

\section{Candida isolates}

Three Candida species, C. albicans, C. tropicalis, and C. glabrata were obtained from King Khalid Hospital, Riyadh, Saudi Arabia. The fresh inoculum was prepared by subculturing each Candida species onto Sabouraud dextrose agar (SDA) medium at $35^{\circ} \mathrm{C}$ for $48 \mathrm{~h}$.

\section{Preparation of candidal inoculum}

SDA slants were prepared and inoculated with different Candida species. The fungus was harvested using $5 \mathrm{~mL}$ sterile saline solution. The absorbance of the fungal suspension was measured at $560 \mathrm{~nm}$ using a spectrophotometer and the cell count was adjusted to attain a viable cell count of $10^{7} \mathrm{CFU} / \mathrm{mL}$ for each Candida species.

\section{Anticandidal bioassay}

The anticandidal activity of different $S$. aromaticum extracts was evaluated by the disc diffusion method. The anticandidal bioassay was performed to evaluate the antifungal potency of the extract, in which 10 $\mathrm{mL}$ SDA medium was poured into the sterile petri dishes as a basal layer, followed by the addition of $15 \mathrm{~mL}$ seeded medium previously inoculated with the prepared microbial suspension ( $1 \mathrm{~mL}$ of fungal suspension $/ 100 \mathrm{~mL}$ of medium) to attain a viable cell count of $10^{5} \mathrm{CFU} / \mathrm{mL}$. The sterilized filter paper discs (diameter $8 \mathrm{~mm}$ ) were loaded with $10 \mathrm{mg}$ of different clove extracts and placed over the seeded plates after solidification $[25,26]$. Terbinafine was used as a positive control at a concentration of $50 \mu \mathrm{g} /$ disk according to CLSI guidelines. Interpretation criteria of terbinafine as the antifungal agent corresponding to the inhibition zone diameter was as follows: $\geq 20 \mathrm{~mm}$, 
sensitive; $12-19 \mathrm{~mm}$, dose-dependent; $\leq 11 \mathrm{~mm}$, resistance [27]. Eugenol (Sigma-Aldrich, USA), the main active constituent of clove, was also used as a standard phytoactive compound. Sterile filter paper discs loaded with $50 \mu \mathrm{g}$ of eugenol were placed over the seeded plates [28]. The plates were incubated at $4{ }^{\circ} \mathrm{C}$ for $2 \mathrm{~h}$ to allow the diffusion of the clove extracts throughout the medium. The plates were further incubated at $35^{\circ} \mathrm{C}$ for $48 \mathrm{~h}$ and the inhibition zone diameter was measured using a Vernier caliper as an indication of antifungal activity.

Determination of minimum inhibitory concentration (MIC) MIC was defined as the lowest concentration of plant extract exhibiting antifungal activity. MIC was evaluated only for the ethyl acetate extract of $S$. aromaticum as the most effective clove extract. SDA medium $(15 \mathrm{~mL})$ was poured into a sterile petri dish as a basal layer, followed by the addition of $10 \mathrm{~mL}$ seeded medium (as described above), and allowed to solidify. Sterile filter paper discs (diameter $8 \mathrm{~mm}$ ) loaded with different concentrations of $S$. aromaticum ethyl acetate extract $(0.125,0.25,0.50,1.0,2.0$ and $4.0 \mathrm{mg} / \mathrm{disc}$ ) were placed over the seeded medium. The plates were incubated at $5{ }^{\circ} \mathrm{C}$ to allow extract diffusion. The plates were then incubated at $35^{\circ} \mathrm{C}$ for $48 \mathrm{~h}$ and the inhibition zone diameter was measured using a Vernier caliper. The lowest concentration that exhibited antifungal activity against Candida species was recorded as the MIC.

\section{Determination of minimum fungicidal concentration}

Minimum fungicidal concentration (MFC) was defined as the lowest concentration of the clove extract exhibiting fungicidal activity. Streaks obtained from the inhibition zone area of MIC and two successive concentrations were cultured on freshly prepared SDA plates. The plates were incubated at $35^{\circ} \mathrm{C}$ for $48 \mathrm{~h}$ and the lowest concentration that exhibited no fungal growth was recorded as MFC.

\section{Gas chromatography-mass spectrometry (GC-MS) analysis} of $S$. aromaticum extracts

Phytochemical analysis of the $S$. aromaticum extracts was performed by GC-MS for the detection of active compounds exhibiting antifungal activity. The GC-MS analysis was performed using the GC-MS Thermo Trace GC Ultra / TSQ Quantum GC. The phytochemical analysis was performed using a TR5-MS capillary column, $(30 \mathrm{~m} \times 0.25 \mathrm{~mm} ; 0.25 \mu \mathrm{m}$ film thickness $)$. The oven was programmed to a ramp rate of $6^{\circ} \mathrm{C} / \mathrm{min}$ to increase the temperature from 40 to $200{ }^{\circ} \mathrm{C}$. The operating conditions were as follows: helium as a carrier gas with a flow rate of $1 \mathrm{~mL} / \mathrm{min}$, injector and detector
Table 1 Antimicrobial activity of different S. aromaticum extracts against Candida strains

\begin{tabular}{llll}
\hline $\begin{array}{l}\text { S. aromaticum extracts } \\
\text { (10 mg/ disc) }\end{array}$ & \multicolumn{3}{l}{$\begin{array}{l}\text { Inhibition zone diameter }(\mathrm{mm}) \\
\text { Candida strains }\end{array}$} \\
\cline { 2 - 4 } & C. albicans & C. glabrata & C. tropicalis \\
\hline Diethyl ether extract & $19.43 \pm 0.15$ & $15.93 \pm 0.15$ & $23.70 \pm 0.17$ \\
Ethyl acetate extract & $20.93 \pm 0.32$ & $14.90 \pm 0.21$ & $30.77 \pm 0.95$ \\
Methanolic extract & $16.03 \pm 0.83$ & $12.93 \pm 0.20$ & $25.60 \pm 1.16$ \\
N-hexane extract & $18.93 \pm 0.03$ & $14.07 \pm 0.09$ & $30.37 \pm 0.26$ \\
Control $(50 \mu \mathrm{gg} /$ disc) & $21.50 \pm 0.06$ & $9.60 \pm 0.06$ & $24.33 \pm 0.13$ \\
Eugenol & $15.67 \pm 0.34$ & $11.21 \pm 0.24$ & $19.93 \pm 0.42$ \\
\hline
\end{tabular}

temperatures were $250^{\circ} \mathrm{C}$, split ratio was $1: 50$. The conditions for mass spectrometry were as follows: mass range from $\mathrm{m} / \mathrm{z}, 40-400 \mathrm{amu}$; ionization potential $70 \mathrm{eV}$; electron multiplier energy $2000 \mathrm{~V}$. The chemical constituents of the clove bud extracts were identified by comparing the results of the GC-MS analysis with the reference retention time and spectral mass data of the NIST database.

\section{Cytotoxicity assay}

The human hepatoma (HUH7) cell line was obtained from the Zoology department, College of Science, King Saud University, Saudi Arabia. The toxicity of different clove extracts of diethyl ether, ethyl acetate, methanol, and n-hexane against the HUH7 cell line was evaluated using the 3-(4,5-dimethylthiazol)-2,5diphenyl tetrazolium bromide (MTT) assay [29]. The cells were cultured in minimal essential medium (Sigma-Aldrich, USA) supplemented with $0.1 \%$ gentamicin (Virbac) and 5\% fetal calf serum (AdcockIngram), incubated in a $5 \% \mathrm{CO}_{2}$ incubator. $\mathrm{HUH7}$ cells were inoculated in 96-well plates and incubated at $37^{\circ} \mathrm{C}$ for $24 \mathrm{~h}$ in an $5 \% \mathrm{CO}_{2}$ incubator for cell adherence to the plate. The crude clove extracts were redissolved in methanol $(10 \mathrm{mg} / \mathrm{mL})$, and appropriate dilutions were prepared. Cells were treated with the extracts of concentrations ranging from 0.0065 to 1

Table 2 Minimum inhibitory concentrations of S. aromaticum ethyl acetate extract against pathogenic Candida strains

\begin{tabular}{llll}
\hline $\begin{array}{l}\text { Concentration of } \\
\text { extract (mg/disc) }\end{array}$ & \multicolumn{3}{l}{ Inhibition zone diameter (mm) of Candida strains } \\
\cline { 2 - 4 } & C. albicans & C. glabrata & C. tropicalis \\
\hline 0.125 & $0.0 \pm 0.0$ & $0.0 \pm 0.0$ & $0.0 \pm 0.0$ \\
0.250 & $0.0 \pm 0.0$ & $0.0 \pm 0.0$ & $8.40 \pm 0.06$ \\
0.500 & $8.83 \pm 0.16$ & $8.07 \pm 0.09$ & $13.40 \pm 0.17$ \\
1.000 & $13.77 \pm 0.72$ & $11.30 \pm 0.12$ & $20.73 \pm 0.72$ \\
2.000 & $15.73 \pm 0.03$ & $12.60 \pm 0.06$ & $23.10 \pm 0.17$ \\
4.000 & $16.83 \pm 0.32$ & $13.83 \pm 0.38$ & $24.17 \pm 0.20$ \\
\hline
\end{tabular}




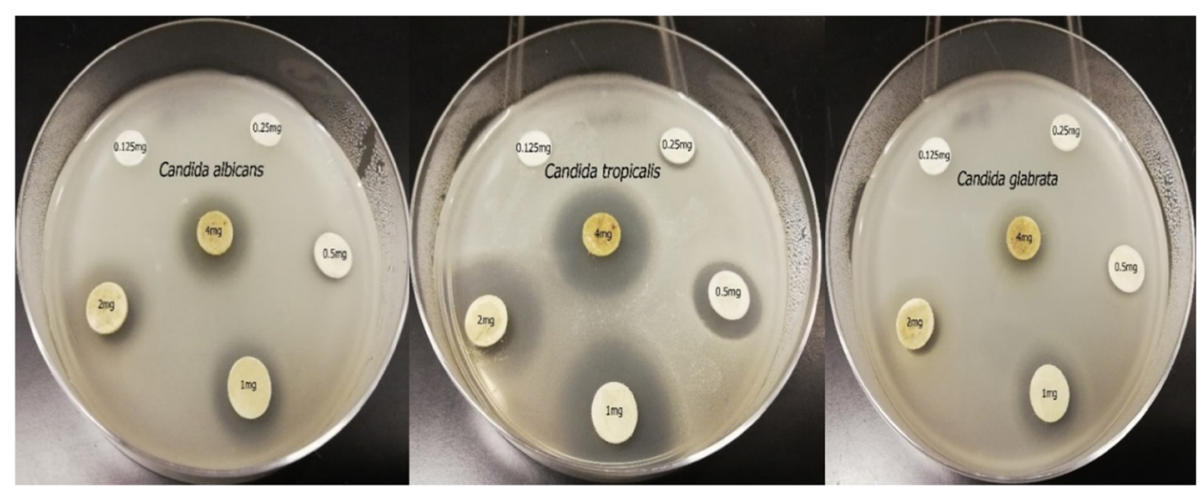

Fig. 1 Minimum inhibitory concentration of S. aromaticum ethyl acetate extract against Candida species

$\mathrm{mg} / \mathrm{ml}$. After treatment for $48 \mathrm{~h}$, the supernatant was removed and the developing solution (MTT) was added at a concentration of $5 \mathrm{mg} / \mathrm{mL}$ to the wells for the formation of formazan crystals. The plates were incubated at $37^{\circ} \mathrm{C}$ for $4 \mathrm{~h}$ and supernatants were removed. Finally, $50 \mu \mathrm{L}$ of dimethyl sulfoxide (DMSO) was added to the wells, stabilizing the formed formazan crystals. Absorbance of the soluble formazan in plates was measured at a wavelength of $570 \mathrm{~nm}$. The absorbance corresponding to the concentration inducing a $50 \%$ inhibition of cell viability $\left(\mathrm{IC}_{50}\right)$ was calculated.

\section{Statistical analysis}

The susceptibility of Candida to different clove extracts was analyzed with GraphPad Prism 5.0 (GraphPad Software, Inc., La Jolla, CA, USA) using one-way analysis of variance and Tukey's test. The data are presented as mean \pm standard error for triplicates. The data were considered statistically significant when the $P$-value was less than 0.05 .

\section{Results}

\section{Extract yield}

The highest S. aromaticum extract yield (6.09\%) was obtained using diethyl ether, followed by methanol (4.67\%), n-hexane (3.02\%), and ethyl acetate (2.57\%).

\section{Anticandidal activity}

Screening the antifungal activity of different $S$. aromaticum extracts against Candida species was performed to evaluate the most effective solvent for extraction of active ingredients. All clove extracts exhibited antifungal activity against the different Candida strains, with different susceptibility patterns. The ethyl acetate extract of $S$. aromaticum was the most effective extract, demonstrating a high antifungal efficiency against C. albicans, C. glabrata, and $C$. tropicalis, with inhibition zone diameters of 20.9, 14.9, and $30.7 \mathrm{~mm}$, respectively. The methanolic clove extract of exhibited antifungal potency against all tested Candida strains, with inhibition zone diameters of $16.03,12.93$, and $25.6 \mathrm{~mm}$. The inhibition zone diameters of the diethyl ether extract were 19.43, 15.93, and $23.7 \mathrm{~mm}$, respectively (Table 1). C. albicans and $C$. tropicalis were sensitive, while $C$. glabrata was more resistant to the antifungal agent terbinafine with inhibition zone diameters of 21.5, 24.33, and $9.6 \mathrm{~mm}$, respectively. In addition, eugenol was used as a standard component of $S$. aromaticum extracts, exhibiting antifungal potency against all evaluated (C. albicans, C. glabrata, and C. tropicalis) strains, with inhibition zone diameters of 15.67 , 11.21 , and $19.93 \mathrm{~mm}$, respectively. The ethyl acetate clove extract was highly effective compared with the control (terbinafine), indicating a high efficiency against $C$. glabrata and $C$. tropicalis, significantly higher $(P<0.05)$ than the control.

\section{MIC and MFC of S. aromaticum ethyl acetate extract}

The MIC of S. aromaticum ethyl acetate extract against C. tropicalis was $0.25 \mathrm{mg} / \mathrm{disc}$, with an inhibition zone

Table 3 Phytochemical components of S. aromaticum ethyl acetate extract

\begin{tabular}{lllll}
\hline Compounds & $\begin{array}{l}\text { Chemical } \\
\text { formula }\end{array}$ & M.W. & $\begin{array}{l}\text { Retention } \\
\text { time (min.) }\end{array}$ & $\begin{array}{l}\text { \% of } \\
\text { Total }\end{array}$ \\
\hline Eugenol & $\mathrm{C}_{10} \mathrm{H}_{12} \mathrm{O}_{2}$ & 164 & 16.33 & 58.88 \\
trans-Caryophyllene & $\mathrm{C}_{15} \mathrm{H}_{24}$ & 204 & 17.41 & 14.44 \\
a-Humulene & $\mathrm{C}_{15} \mathrm{H}_{24}$ & 204 & 18.31 & 1.88 \\
Eugenol acetate & $\mathrm{C}_{12} \mathrm{H}_{14} \mathrm{O}_{3}$ & 206 & 20.27 & 23.86 \\
Longipinocarvone & $\mathrm{C}_{15} \mathrm{H}_{22} \mathrm{O}$ & 218 & 21.30 & 0.19 \\
Caryophyllene oxide & $\mathrm{C}_{15} \mathrm{H}_{24} \mathrm{O}$ & 220 & 21.45 & 0.74 \\
\hline
\end{tabular}

M.W. Molecular weight 


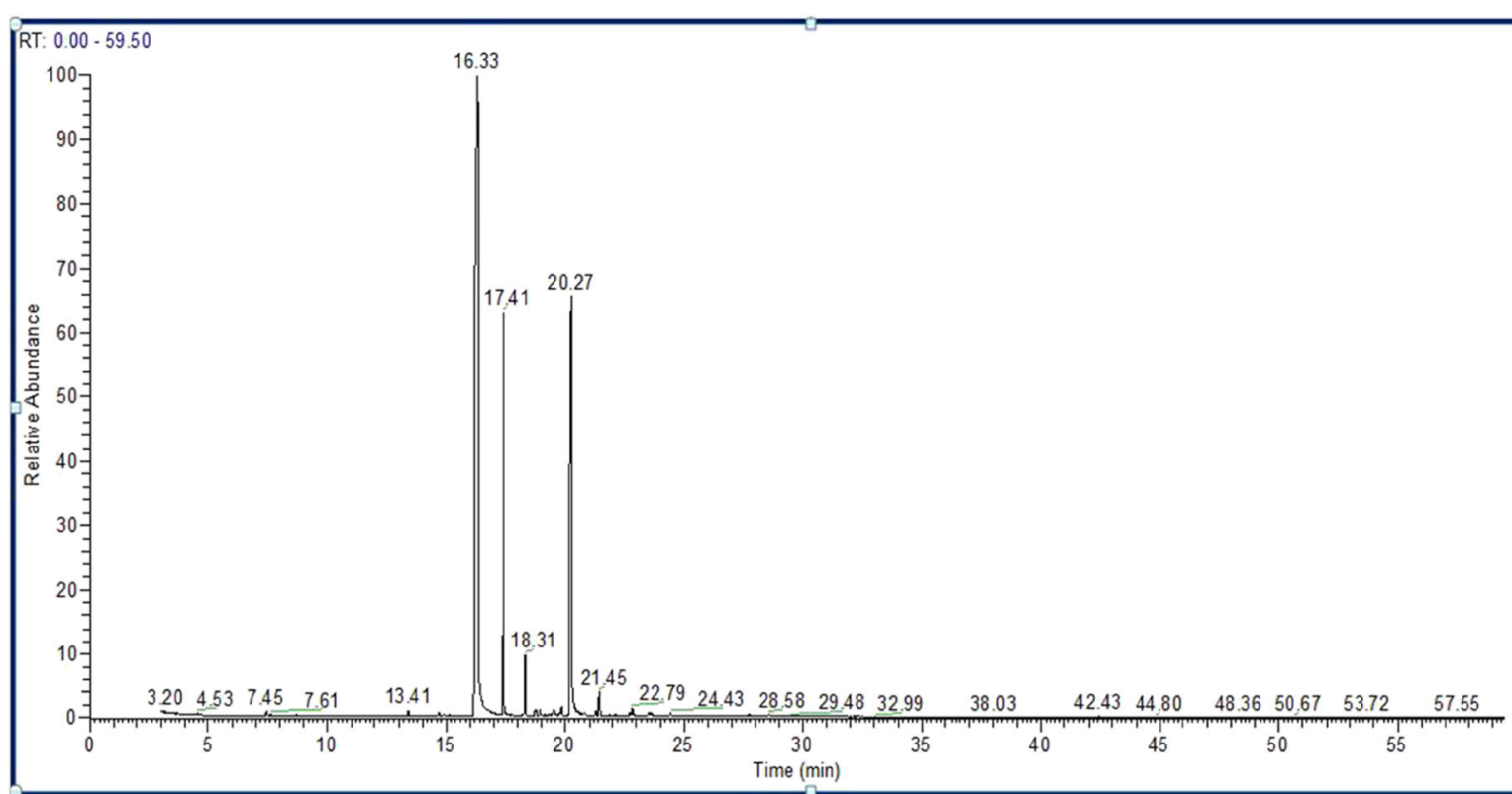

Fig. 2 Chromatogram of S. aromaticum ethyl acetate extract

diameter of $8.4 \mathrm{~mm}$. The MIC against C. albicans and C. glabrata was $0.5 \mathrm{mg} /$ disc, with inhibition zone diameters of 8.83 and $8.07 \mathrm{~mm}$, respectively (Table 2). The MIC of $S$. aromaticum ethyl acetate extract against $C$. tropicalis was lower than that against both $C$. albicans and C. glabrata. Hence, $C$. tropicalis the most sensitive to this clove extract (Fig. 1). The MFC of the $S$. aromaticum extract against $C$. tropicalis was $0.5 \mathrm{mg} / \mathrm{disc}$ as no growth of Candida was observed at this concentration. Similarly, no C. albicans and C. glabrata growth was observed at $1 \mathrm{mg} /$ disc.

Gas chromatography-mass spectrometry analysis (GC-MS) of $S$. aromaticum extracts

GC-MS analysis of $S$. aromaticum ethyl acetate extract revealed that eugenol (58.88\%) was the most abundant active component, followed by eugenyl acetate (23.86\%), trans-caryophyllene (14.44\%), $\alpha$ humulene $(1.88 \%)$, caryophyllene oxide $(0.74 \%)$, and longipinocarvone (0.19\%) (Table 3 and Fig. 2). Furthermore, the main bioactive component of the diethyl ether extract was eugenol (66.48\%), followed by eugenyl acetate (31.73\%), trans-caryophyllene (1.63\%), caryophyllene oxide $(0.31 \%)$, and $\alpha$-humulene $(0.21 \%)$ (Table 4 and Fig. 3). In contrast, new phytochemical constituents detected in the $S$. aromaticum methanolic extract included musk ketone (2.78\%), $\alpha$ cubebene $(0.79 \%)$, chavicol $(0.78 \%), \quad \beta$-cadinene $(0.59 \%)$, and $\alpha$-farnesene $(0.37 \%)$. Other constituents such as eugenol (55.58\%), eugenyl acetate (19.83\%), trans-caryophyllene $(15.71 \%), \alpha$-humulene $(2.46 \%)$, and caryophyllene oxide $(1.10 \%)$ were also detected (Table 5 and Fig. 4). Similarly, eugenol (61.37\%) was the most abundant bioactive component in the nhexane extract (Table 6 and Fig. 5).

\section{Cytotoxicity assay}

The diethyl ether clove extract demonstrated the lowest toxic effect against the HUH7 cell line, with a relative $\mathrm{IC}_{50}$ of $62.43 \mu \mathrm{g} / \mathrm{ml}$, while higher toxicity of was detected with the methanolic extract, with an $\mathrm{IC}_{50}$ of $24.17 \mu \mathrm{g} / \mathrm{ml}$. Moreover, the $\mathrm{n}$-hexane and ethyl acetate extracts of clove exhibited moderate toxicity against $\mathrm{HUH7}$ cells with relative $\mathrm{IC}_{50}$ values of 42.19 and 33.68, respectively (Fig. 6).

Table 4 Phytochemical components of S. aromaticum diethyl ether extract

\begin{tabular}{lllll}
\hline Compounds & $\begin{array}{l}\text { Chemical } \\
\text { formula }\end{array}$ & M.W. & $\begin{array}{l}\text { Retention } \\
\text { time (min.) }\end{array}$ & $\begin{array}{l}\text { \% of } \\
\text { Total }\end{array}$ \\
\hline Eugenol & $\mathrm{C}_{10} \mathrm{H}_{12} \mathrm{O}_{2}$ & 164 & 16.21 & 66.48 \\
trans-Caryophyllene & $\mathrm{C}_{15} \mathrm{H}_{24}$ & 204 & 17.38 & 1.63 \\
a-Humulene & $\mathrm{C}_{15} \mathrm{H}_{24}$ & 204 & 18.29 & 0.21 \\
Eugenol acetate & $\mathrm{C}_{12} \mathrm{H}_{14} \mathrm{O}_{3}$ & 206 & 20.21 & 31.37 \\
Caryophyllene oxide & $\mathrm{C}_{15} \mathrm{H}_{24} \mathrm{O}$ & 220 & 21.44 & 0.31 \\
\hline
\end{tabular}

M.W. Molecular weight 


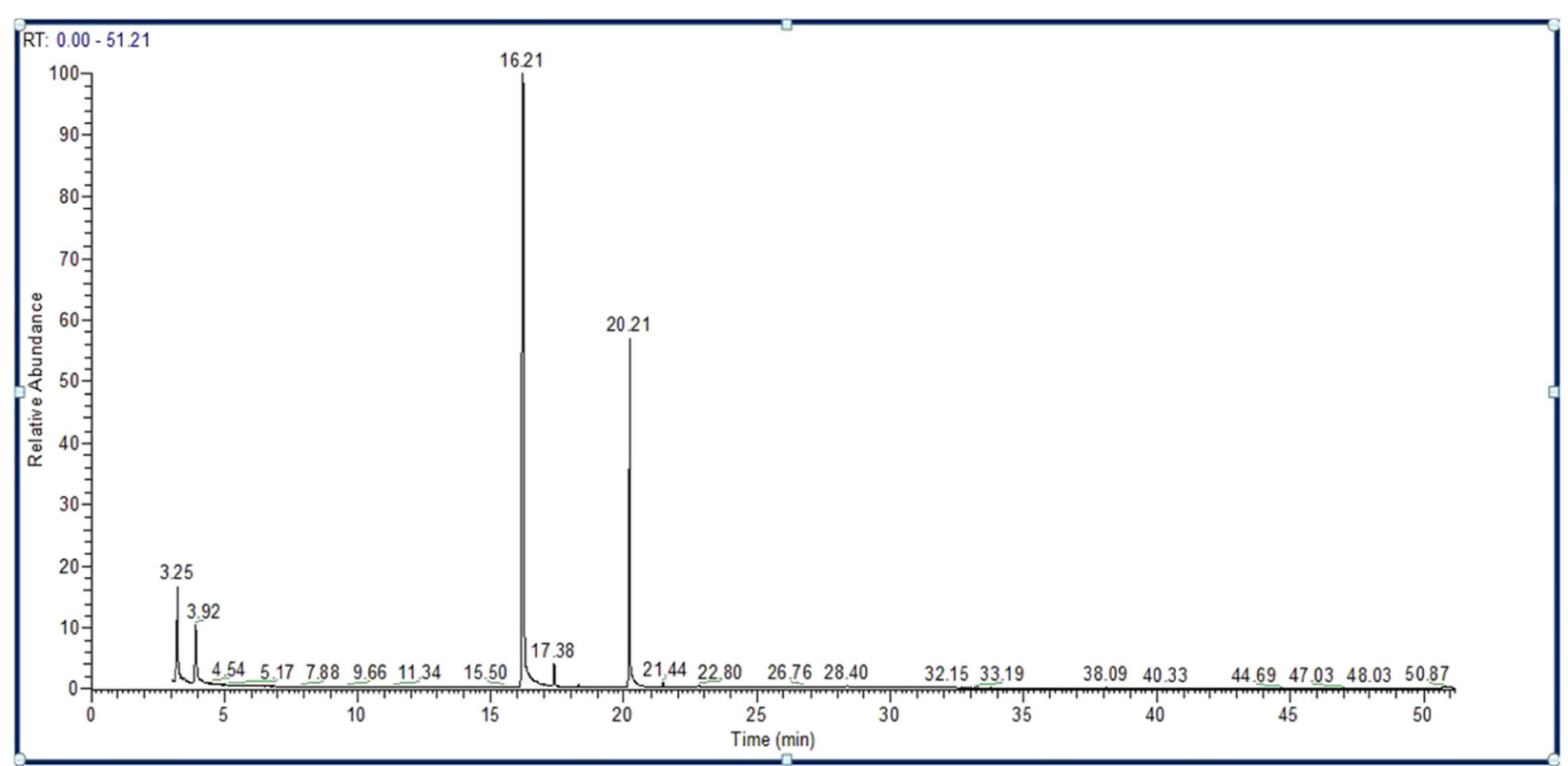

Fig. 3 Chromatogram of S. aromaticum diethyl ether extract

\section{Discussion}

All extracts of $S$. aromaticum exhibited antifungal activity against the concerned candidal strains evaluated in this study (Table 1). These results concurred with those of Mansourian et al., demonstrating that $S$. aromaticum extracts $(10 \mathrm{mg} / 100 \mu \mathrm{l})$ possessed antifungal activity against $C$. albicans, with an inhibition zone diameter of $29.6 \mathrm{~mm}$ [25]. Reportedly, clove extracts possess antioxidant and antimicrobial properties due to the presence of phenolic compounds, such as flavonoids, hydroxybenzoic acids, and hydroxyphenyl propenes [30].

Table 5 Phytochemical components of S. aromaticum methanolic extract

\begin{tabular}{lllll}
\hline Compounds & $\begin{array}{l}\text { Chemical } \\
\text { formula }\end{array}$ & M.W. & $\begin{array}{l}\text { Retention } \\
\text { time (min) }\end{array}$ & $\begin{array}{l}\text { \% of } \\
\text { total }\end{array}$ \\
\hline Chavicol & $\mathrm{C}_{9} \mathrm{H}_{10} \mathrm{O}$ & 134 & 14.09 & 0.78 \\
a-Cubebene & $\mathrm{C}_{15} \mathrm{H}_{24}$ & 204 & 15.50 & 0.79 \\
Eugenol & $\mathrm{C}_{10} \mathrm{H}_{12} \mathrm{O}_{2}$ & 164 & 16.44 & 55.58 \\
trans-Caryophyllene & $\mathrm{C}_{15} \mathrm{H}_{24}$ & 204 & 17.46 & 15.71 \\
a-Humulene & $\mathrm{C}_{15} \mathrm{H}_{24}$ & 204 & 18.32 & 2.46 \\
a-Farnesene & $\mathrm{C}_{15} \mathrm{H}_{24}$ & 204 & 19.50 & 0.37 \\
B-Cadinene & $\mathrm{C}_{15} \mathrm{H}_{24}$ & 204 & 19.84 & 0.59 \\
Eugenol acetate & $\mathrm{C}_{12} \mathrm{H}_{14} \mathrm{O}_{3}$ & 206 & 20.33 & 19.83 \\
Caryophyllene oxide & $\mathrm{C}_{15} \mathrm{H}_{24} \mathrm{O}$ & 220 & 21.47 & 1.10 \\
Musk ketone & $\mathrm{C}_{14} \mathrm{H}_{18} \mathrm{~N}_{2} \mathrm{O}_{5}$ & 294 & 29.52 & 2.78 \\
\hline
\end{tabular}

M.W. Molecular weight
Phytochemical analysis of the $S$. aromaticum ethyl acetate extract demonstrated that eugenol was the most abundant active component (58.88\%), followed by eugenyl acetate (23.86\%), trans-caryophyllene $(14.44 \%)$, and $\alpha$-humulene (1.88\%). These phytochemicals were consistent with the study by Jirovetz et al., who reported that eugenol was the most abundant active phytochemical component, constituting $76.8 \%$ of the total active compound [31]. Additionally, similar results were reported by Chaieb et al., demonstrating that clove oil was predominantly composed of eugenol (70\%), followed by eugenyl acetate $(5.6 \%)$, and $\beta$-caryophyllene $(1.4 \%)$ [32]. The high efficiency of the ethyl acetate clove extract as an antifungal agent offers a potential natural anticandidal drug for the treatment of Candida vaginitis, avoiding the side effects associated with several chemotherapeutic agents used in the treatment of vaginitis. In addition, Chami et al. ascertained that clove extract constituents are a promising source for the curative and prophylactic therapy of vulvovaginal candidiasis [33]. The inhibition zone diameters recorded with eugenol $(50 \mu \mathrm{g})$ as a standard compound against the concerned Candida species were less than those recorded for the crude clove extract $(10 \mathrm{mg})$. These results may be attributed to the high content of eugenol in different extracts, confirmed by GC-MS analysis of clove. GC-MS analysis of $S$. aromaticum extracts (diethyl ether, ethyl acetate, n-hexane, and methanolic) revealed that eugenol was the main active 


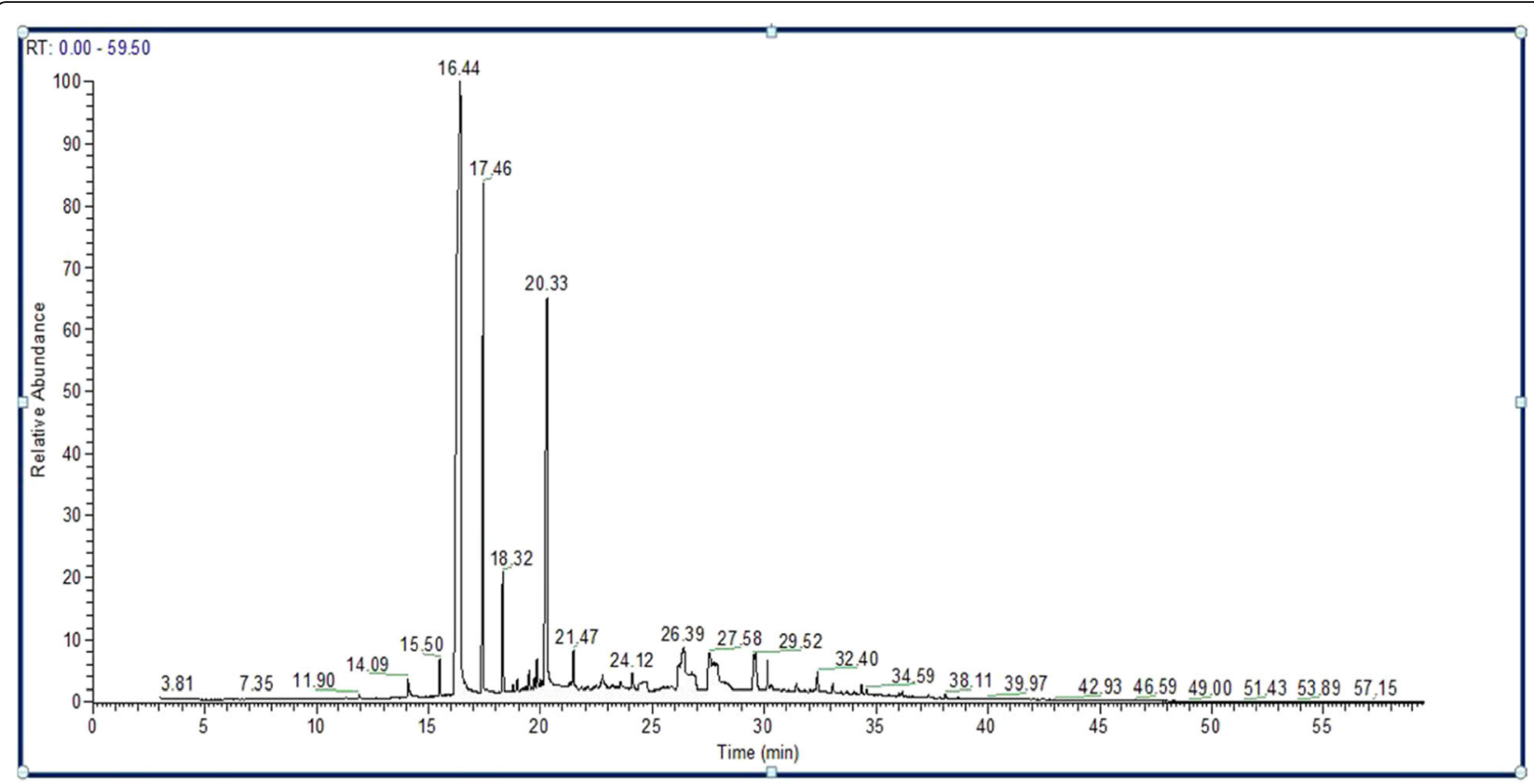

Fig. 4 Chromatogram of S. aromaticum methanolic extract

compound, with relative percentages of 66.48 , $58.88,55.58$, and $61.37 \%$, respectively.

Eugenol exhibited antifungal potency against $C$. albicans strains, demonstrating inhibition zone diameters of $15.67 \mathrm{~mm}$. This result was consistent with that of Pavesi et al., who detected the potency of eugenol at a concentration of $57 \mu \mathrm{g} /$ disk against C. albicans, with an inhibition zone diameter of $12.1 \mathrm{~mm}$ [28]. In the present study, the ethyl acetate clove extract demonstrated the highest antifungal efficacy against the different Candida species compared to the other solvent extracts evaluated. The antifungal potency of $S$. aromaticum could be attributed to the high eugenol content of clove extracts, which inhibits the biosynthesis of ergosterol, a component of the microbial cell membranes. These may lead to the disruption of microbial cell

Table 6 Phytochemical components of S. aromaticum n-hexane extract

\begin{tabular}{lllll}
\hline Compounds & $\begin{array}{l}\text { Chemical } \\
\text { formula }\end{array}$ & M.W. & $\begin{array}{l}\text { Retention } \\
\text { time (min.) }\end{array}$ & $\begin{array}{l}\text { \% of } \\
\text { Total }\end{array}$ \\
\hline Eugenol & $\mathrm{C}_{10} \mathrm{H}_{12} \mathrm{O}_{2}$ & 164 & 16.27 & 61.37 \\
trans-Caryophyllene & $\mathrm{C}_{15} \mathrm{H}_{24}$ & 204 & 17.39 & 0.52 \\
a-Humulene & $\mathrm{C}_{15} \mathrm{H}_{24}$ & 204 & 18.30 & 0.34 \\
Eugenol acetate & $\mathrm{C}_{12} \mathrm{H}_{14} \mathrm{O}_{3}$ & 206 & 20.26 & 34.95 \\
Caryophyllene oxide & $\mathrm{C}_{15} \mathrm{H}_{24} \mathrm{O}$ & 220 & 21.45 & 0.82 \\
\hline
\end{tabular}

M.W. Molecular weight membrane permeability causing cell death [34]. Other researchers have attributed the antifungal activity to eugenyl acetate which inhibits germ tube formation, prevents the formation of candidal biofilms, and enhances phagocytic activity of macrophages against the C. albicans species [35]. The current study revealed that $S$. aromaticum extracts exhibited strong antifungal potency against Candida species at low concentrations $(250 \mu \mathrm{g} /$ disc $)$. Hence, it could be used as a potential source of natural antifungal drugs. The cytotoxicity assay confirmed that the diethyl ether clove extract possessed the lowest toxicity, while the ethyl acetate extract exhibited moderate toxicity against the $\mathrm{HUH} 7$ cancer cell lines, with $\mathrm{IC}_{50}$ values of 62.43 and $33.68 \mu \mathrm{g} / \mathrm{ml}$ respectively. These results were in accordance with that of Kumar et al. who have reported clove oil toxicity against MCF-7 human breast cancer cell lines, with an $\mathrm{IC}_{50}$ value of $36.43 \mu \mathrm{g} / \mathrm{ml}$ [36]. Vijayasteltar et al. have demonstrated the safety of clove bud extracts as dietary supplements in Wistar rats, confirming the absence of toxicological changes in behavioral observations, body weights, organ weights, ophthalmic examinations, feed consumption, hematology, urinalysis, and clinical biochemistry parameters compared to the untreated group of animals [37].

\section{Conclusion}

Syzygium aromaticum extracts exhibited a highly antifungal efficiency against the most common and 


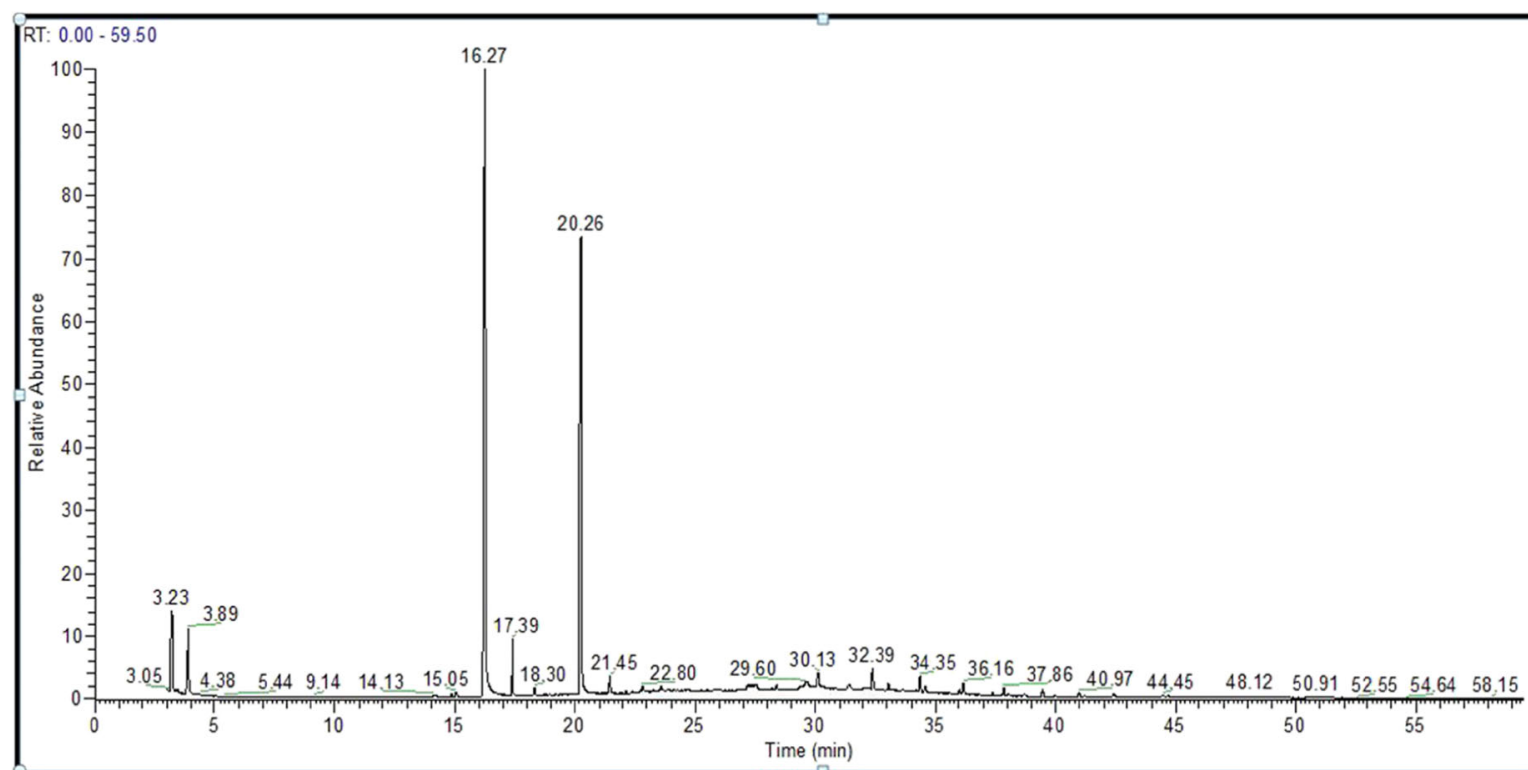

Fig. 5 Chromatogram of S. aromaticum n-hexane extract

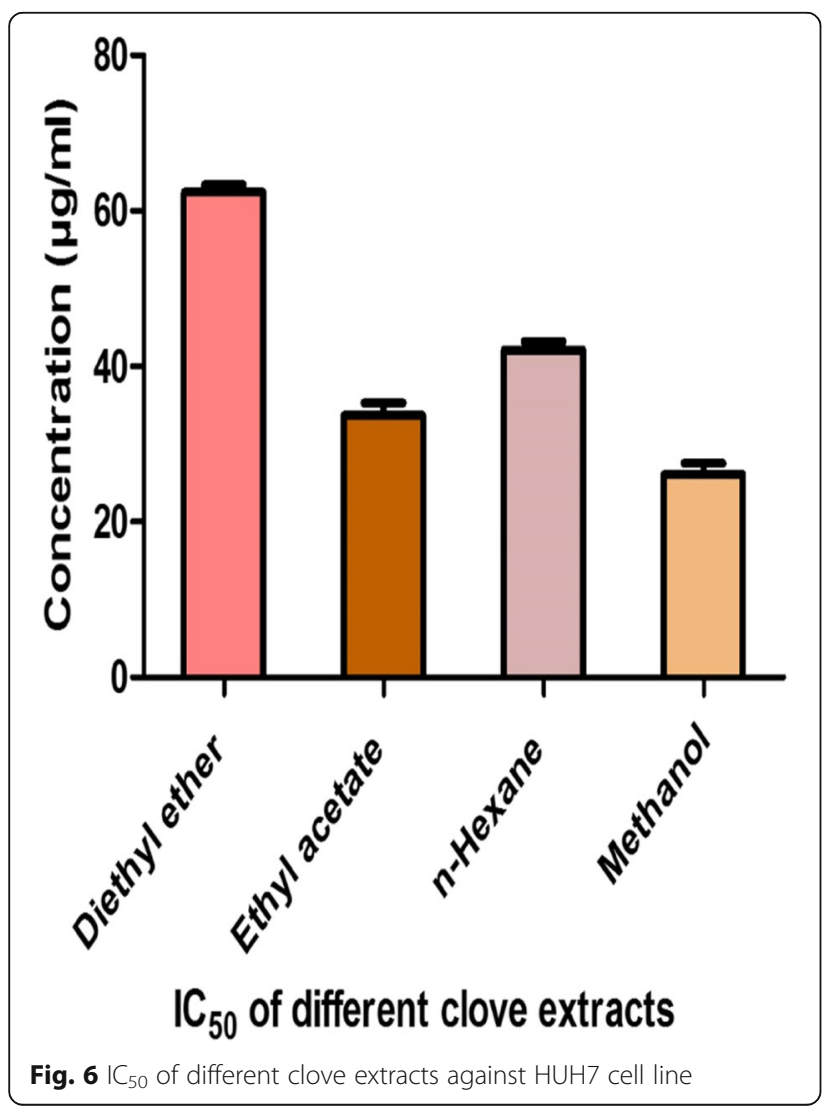

predominant strains causing candidal vaginitis. Ethyl acetate was the most effective organic solvent in the extraction process, producing a high yield of clove active constituents. Furthermore, the results demonstrated a high potency of the clove extract compared with terbinafine (control). Hence, it could be used as a natural, safe, and effective antifungal agents. Moreover, it could be prescribed as a substitute to several chemotherapeutic agents used in the candidal vaginitis therapy for external use, eliminating the extensive side effects associated with these chemical agents, especially in pregnant women.

\section{Abbreviations}

CFU: Colony forming unit; GC-MS: Gas Chromatography-Mass Spectrometry; HUH7: Human hepatoma cell line; $I_{50}$ : The half maximal inhibitory concentration; MFC: Minimum fungicidal concentration; MIC: Minimum inhibitory concentration; MTT: 3-(4,5-dimethylthiazol)-2,5-diphenyl tetrazolium bromide; SDA: Sabouraud dextrose agar

\section{Acknowledgments}

The authors extend their appreciation to the Deanship of Scientific Research at King Saud University for funding this work through research group No. (RGP-1440-094).

\section{Authors' contributions}

MTY designed the study, performed the experiments, analyzed the data statistically, and wrote the original draft. AAM helped in the writing, reviewing, and editing of the manuscript. AAA contributed reagents and materials. All authors read and approved the final manuscript.

\section{Funding}

Deanship of Scientific Research at King Saud University through research. Group No. (RGP-1440-094).

\section{Availability of data and materials}

The datasets used and/or analyzed during the current study is available from the corresponding author on reasonable request. 


\section{Ethics approval and consent to participate}

Not applicable.

\section{Consent for publication}

Not applicable.

\section{Competing interests}

The authors declare that they have no competing interests.

Received: 20 July 2019 Accepted: 17 January 2020

Published online: 30 January 2020

\section{References}

1. Farhan MA, Moharram AM, Salah T, Shaaban OM. Types of yeasts that cause vulvovaginal candidiasis in chronic users of corticosteroids. Med Mycol, 2018. https://doi.org/10.1093/mmy/myy 117 .

2. Borges S, Silva J, Teixeira P. The role of lactobacilli and probiotics in maintaining vaginal health. Arch Gynecol Obstet. 2014;289(3):479-89.

3. Corsello S, Spinillo A, Osnengo G, Penna C, Guaschino S, Beltrame A, et al. An epidemiological survey of vulvovaginal candidiasis in Italy. Eur J Obstet Gynecol Reprod Biol. 2003;110(1):66-72.

4. Sojakova M, Liptajova D, Borovsky M, Subik J. Fluconazole and itraconazole susceptibility of vaginal yeast isolates from Slovakia. Mycopathologia. 2004; 157(2):163-9.

5. Richter SS, Galask RP, Messer SA, Hollis RJ, Diekema DJ, Pfaller MA. Antifungal susceptibilities of Candida species causing vulvovaginitis and epidemiology of recurrent cases. J Clin Microbiol. 2005;43(5):2155-62.

6. Grigoriou O, Baka S, Makrakis E, Hassiakos D, Kapparos G, Kouskouni E. Prevalence of clinical vaginal candidiasis in a university hospital and possible risk factors. Eur J Obstet Gynecol Reprod Biol. 2006;126(1):121-5.

7. Nelson M, Wanjiru W, Margaret MW. Prevalence of vaginal candidiasis and determination of the occurrence of Candida species in pregnant women attending the antenatal clinic of Thika District hospital, Kenya. Open J Med Microbiol. 2013;3:264.

8. Bauters TG, Dhont MA, Temmerman MI, Nelis HJ. Prevalence of vulvovaginal candidiasis and susceptibility to fluconazole in women. Am J Obstet Gynecol. 2002:187:569-74.

9. Pilmis B, Jullien V, Sobel J, Lecuit M, Lortholary O, Charlier C. Antifungal drugs during pregnancy: an updated review. J Antimicrob Chemother. 2014; 70(1):14-22.

10. Douglas $\amalg$. Candida biofilms and their role in infection. Trends Microbiol. 2003;11(1):30-6.

11. Schaller M, Borelli C, Korting $H C$, Hube B. Hydrolytic enzymes as virulence factors of Candida albicans. Mycoses. 2005;48(6):365-77.

12. Tamura NK, Negri MFN, Bonassoli LA, Svidzinski TIE. Fatores de virulência de Candida spp isoladas de cateteres venosos e mãos de servidores hospitalares. Rev Soc Bras Med Trop. 2007;40(1):91-3.

13. Silva S, Negri M, Henriques M, Oliveira R, Williams DW, Azeredo J. Candida glabrata, Candida parapsilosis and Candida tropicalis: biology, epidemiology, pathogenicity and antifungal resistance. FEMS Microbiol Rev. 2012;36(2): 288-305.

14. Mayer FL, Wilson D, Hube B. Candida albicans pathogenicity mechanisms. Virulence. 2013:4(2):119-28.

15. Jayatilake J, Samaranayake Y, Cheung L, Samaranayake L. Quantitative evaluation of tissue invasion by wild type, hyphal and SAP mutants of Candida albicans, and non-albicans Candida species in reconstituted human oral epithelium. J Oral Pathol. 2006;35(8):484-91.

16. Beyda ND, John J, Kilic A, Alam MJ, Lasco TM, Garey KW. FKS mutant Candida glabrata: risk factors and outcomes in patients with candidemia. Clin Infect Dis. 2014;59(6):819-25.

17. Nasrollahi Z, Yadegari MH, Roudbar Mohammadi S, Roudbary M, Hosseini Poor M, Nikoomanesh F, et al. Fluconazole resistance Candida albicans in females with recurrent vaginitis and Pir1 overexpression. Jundishapur J Microbiol. 2015:8(9):e21468.

18. Salehei Z, Seifi Z, Mahmoudabadi A. Sensitivity of vaginal isolates of Candida to eight antifungal drugs isolated from Ahvaz. Iran Jundishapur J Microbiol. 2012;5(4):574-7.

19. Chaieb K, Hajlaoui H, Zmantar T, Kahla-Nakbi AB, Rouabhia M, Mahdouani K et al. The chemical composition and biological activity of clove essential oil, Eugenia caryophyllata (Syzigium aromaticum L. Myrtaceae): a short review. Phytother Res. 2007;21(6):501-6.
20. Bouddine L, Louastel B, Achahbar S, Chami N, Chami F, Remmal A. Comparative study of the antifungal activity of some essential oils and their major phenolic components against Aspergillus Niger using three different methods. Afr J Biotechnol. 2012;11(76):14083-7.

21. Sebaaly C, Jraij A, Fessi H, Charcosset C, Greige-Gerges H. Preparation and characterization of clove essential oil-loaded liposomes. Food Chem. 2015 178:52-62.

22. Khan R, Islam B, Akram M, Shakil S, Ahmad AA, Ali SM, Ali M, Siddiqui M, Khan A. Antimicrobial activity of five herbal extracts against multi drug resistant (MDR) strains of bacteria and fungus of clinical origin. Molecules. 2009:14(2):586-97.

23. Gonelimali FD. Lin J, Miao W, Xuan J, Charles F, Chen M, Hatab SR, Antimicrobial properties and mechanism of action of some plant extracts against food pathogens and spoilage microorganisms. Front Microbiol. 1639:2018(9).

24. Sahal G, Nasseri B, Ebrahimi A, Bilkay IS. Electrospun essential oilpolycaprolactone nanofibers as antibiofilm surfaces against clinical Candida tropicalis isolates. Biotechnol Lett. 2019;41(4-5):511-22.

25. Mansourian A, Boojarpour N, Ashnagar S, Beitollahi JM, Shamshiri A. The comparative study of antifungal activity of Syzygium aromaticum, Punica granatum and nystatin on Candida albicans; an in vitro study. J Mycol Med. 2014:24(4):e163-8.

26. Mostafa AA, Al-Askar AA, Almaary KS, Dawoud TM, Sholkamy EN, Bakri MM. Antimicrobial activity of some plant extracts against bacterial strains causing food poisoning diseases. Saudi J Biol Sci. 2018;25(2): $361-6$

27. Clinical and Laboratory Standards Institute. "Reference Method for Antifungal Disk Diffusion Susceptibility Testing of Yeasts; Approved Guideline," CLSI document M44-A. USA: CLSI, Wayne, PA: Clinical Laboratory Standards Institute 19087-1898; 2004

28. Pavesi $C$, Banks $L A$, Hudaib T. Antifungal and antibacterial activities of eugenol and non-polar extract of Syzygium aromaticum L. J Pharma Sci Res. 2018:10(2):337-9.

29. Famuyide IM, Aro AO, Fasina FO, Eloff JN, McGaw LJ. Antibacterial and antibiofilm activity of acetone leaf extracts of nine under-investigated south African Eugenia and Syzygium (Myrtaceae) species and their selectivity indices. BMC Complement Altern Med. 2019:19(1):141.

30. Neveu V, Perez-Jiménez J, Vos F, Crespy V, du Chaffaut L, Mennen L, et al. Phenol-Explorer: an online comprehensive database on polyphenol contents in foods. Database (Oxford). 2010;2010:bap024.

31. Jirovetz L, Buchbauer G, Stoilova I, Stoyanova A, Krastanov A, Schmidt E. Chemical composition and antioxidant properties of clove leaf essential oil. J Agric Food Chem. 2006;54(17):6303-7.

32. Chaieb K, Zmantar T, Ksouri R, Hajlaoui H, Mahdouani K, Abdelly C, Bakhrouf A. Antioxidant properties of the essential oil of eugenia caryophyllata and its antifungal activity against a large number of clinical Candida species. Mycoses. 2007;50(5):403-6.

33. Chami F, Chami N, Bennis S, Trouillas J, Remmal A. Evaluation of carvacrol and eugenol as prophylaxis and treatment of vaginal candidiasis in an immunosuppressed rat model. J Antimicrob Chemother. 2004;54(5):909-14.

34. de Oliveira PF, Mendes JM, de Oliveira Lima E. Investigation on mechanism of antifungal activity of eugenol against Trichophyton rubrum. Med Mycol. 2013;51(5):507-13.

35. Musthafa KS, Hmoteh J, Thamjarungwong B, Voravuthikunchai SP Antifungal potential of eugenyl acetate against clinical isolates of Candida species. Microb Pathog. 2016;99:19-29.

36. Kumar PS, Febriyanti RM, Sofyan FF, Luftimas DE, Abdulah R. Anticancer potential of Syzygium aromaticum L. in MCF-7 human breast cancer cell lines. Pharmacogn Mag. 2014;6(4):350.

37. Vijayasteltar L, Nair GG, Maliakel B, Kuttan R, Krishnakumar I. Safety assessment of a standardized polyphenolic extract of clove buds: subchronic toxicity and mutagenicity studies. Toxicol Rep. 2016;3:439-49.

\section{Publisher's Note}

Springer Nature remains neutral with regard to jurisdictional claims in published maps and institutional affiliations. 